\section{The Diverse Economies of Housing}

\author{
Adriana Mihaela Soaita \\ University of Glasgow, Glasgow, UK \\ AdrianaMihaela.Soaita@glasgow.ac.uk
}

\begin{abstract}
This paper questions the uncritical transfer of neoliberal concepts, such as financialisation and overreliance on conceptual dichotomies like formal/informal, as the lenses through which to understand practices of housing provision and consumption in the post-communist space. To this end, it introduces the newlyestablished 'diverse economies' framework, which has been used elsewhere to reveal existing and possible alternatives to advanced capitalism. Applied to the Romanian case, the lens of diverse economic practices helps shed light on the ways in which the current housing system was historically constituted, with implications for how housing consumption is now stratified across some related housing typologies. The paper invites debate on the theoretical usefulness of the diverse economies framework to study housing phenomena, particularly its implications for understanding patterns of inequality and poverty, its potential to devise useful analytical categories, and its effect of directing attention to acts of resistance to neoliberal capitalism.
\end{abstract}

Keywords: diverse economies; housing; Romania; post-communism; home-ownership. 


\section{Introduction}

Studies of post-communist housing have become theoretically more engaged and empirically better grounded. Broadly speaking, the 1990s saw efforts to document through expert knowledge the housing legacies of communism and the implications of post-communist privatisation, with some not uncontested conceptualisations of (post-) communist housing models (Clapham et al. 1996; Kemeny and Lowe 1998). After 2000, post-communist housing studies reached broader theoretical debates, including those around path-dependency, institutionalism and welfare regimes (Lux et al. 2017; Soaita and Dewilde 2018; Stephens, Lux and Sunega 2015). Suffice to say, they have become more diverse in terms of theoretical approaches, methods, empirical foci, and disciplinary fields.

The literature grew exponentially over the period. A search in Scopus, one of the largest academic databases, for the word 'housing' in article titles, keywords, and abstracts and in books and book chapters focusing on the area of the former USSR and the Eastern Bloc, returned 301 items published during the 1990s (which is more than the 206 published over the last three decades of communism); 836 items for the 2000s; and 2,703 for the 2010s. ${ }^{1}$

Within my persistent interest in but clearly non-exhaustive knowledge of the burgeoning postcommunist housing literature, I wish to highlight two tendencies against which this article positions its argument: an emerging, rather uncritical transfer of neoliberal concepts such as financialisation (Cada 2018) and a persistent reliance on conceptual binaries, particularly the formal/informal binary, to explain housing phenomena. While I am not denying their value, I would like to counter-balance these views by introducing the framework of 'diverse economies' as a tool for a richer understanding of post-communist housing.

The newly-established scholarship of 'diverse economies' (Gibson-Graham 2008; Smith and Stenning 2006) seems promising to post-communist housing studies, although its aim was to illuminate economic life in advanced capitalist societies. Smith and Stenning (2006) defined the diverse economy as ' $a$ host of economic practices articulated with one another in dynamic and complex ways and in multiple sites and places', and as being suited to linking the market, grey, and black economies with households' and states' welfare/economic practices.

The importance of this paper is twofold. First, it introduces the framework of diverse economies (section 2) and then applies it (section 3) to the historical constitution of the Romanian housing system, with implications for how housing consumption is now stratified across related housing typologies. Second and most important, the paper aims to open an academic conversation around this framework's potential to develop new research questions, analytical categories, and understandings of the links between socioeconomic and housing stratification. Section 4 concisely concludes the paper.

\footnotetext{
${ }^{1}$ While not all these studies may be directly relevant, the 20 authors with 10 or more outputs are well known to post-communist scholars, in descending order: Lux M, Sunega P, Hegedus J, Tammaru T, Kaklauskas A, Kahrik A, Leetmaa K, Mihina S, Ripka G, Hanus A, Tosics I, Zavadskas EK, Broucek J, Fedorko G, Radnai I, Trojanek R, Vucemilo M, Gorczynska M, Mandic C, Molanr V, Turmova E.
} 


\section{Diverse economic practices}

The 'diverse economies' framework draws attention to the economic value of many sociallyembedded activities of households, communities, and social networks situated outside the 'formal' economic space. These other economies are not insignificant, having been estimated to account for between $10 \%$ and $80 \%$ of formal GDP across countries (Schneider and Enste 2000).

To explain the whole economy, Cameron and Gibson-Graham (2003) employed the metaphor of the 'layered cake'; they conceptualised three 'ideal' typologies:

1) The top layer comprises the capitalist economies of the private sector/firms driven by profit-making, where work is paid for and transactions are monetised through formal financial institutions. This includes economic practices/institutions pertaining to speculative development, mortgaged homeownership, or housing financialisation, where consumption is enabled by tax-registered income.

2) The less visible alternative capitalist economies of the non-profit public/third sector and the grey economy. Examples of the former are the economic practices/institutions of social-housing provision and management, with consumption subsidised on the supply or demand side, including discounted privatisation. The latter includes the many grey economies of housing construction and consumption where money moves through hands rather than bank accounts; or new phenomena such as AirBnB. Overall, economic activities are legal but non-profit, (partially) undeclared, or not fully compliant with socially-unaccepted, complex, or hard-to-enforce regulations.

3) The least visible non-capitalist economies of 'benevolence' and 'malevolence', embedded in the non-market spaces of unpaid labour. The former includes DIY/sweatequity, self-building, mutual aid, intergenerational sharing of money or space. Economies of 'malevolence' refer to theft or modern slavery, which have massive implications for housing in some countries (Navarro 2013).

4) However, a fourth typology should be added: the anti-capitalist economy of the communist state, the command economy of shortage, which remains undoubtedly distinct from the public sector of capitalist societies given its centralised delivery of urban flats (Kornai 1992).

The 'diverse economies' framework questions the epistemological and ontological choice of reducing the richness of contemporary economic life to one conceptual category (e.g. neoliberalism) or dichotomy (e.g. formal/informal). Indeed, it aims to unravel the complex ways and the multiple spaces in which economic practices of all sorts articulate between and within the above four ideal typologies, including across their unavoidably fuzzy borders — with the transformative aim of imagining post-capitalist futures. While the 'diverse economies' research established itself in the last decade, it has not escaped well-founded criticism (Samers 2005), particularly in relation to the multiple exclusions, exploitations, and inequalities created even by celebrated economies of care, gifts, and sharing.

'Diverse economies' scholars contributed new knowledge through their focus on 'other worlds' - for example, everyday resilience, ethical finance and economies of sharing, fair-trade, domesticity or night-life. Smith and Stenning (2006) demonstrated that the diverse economies lens is particularly helpful in illuminating everyday life in the post-communist space 
(Pavlovskaya 2004; Smith and Rochovska 2007). Nonetheless, housing scholars have as yet failed to exploit this framework's potential to inform housing research.

\section{Diverse economies of housing provision and consumption in Romania}

A focus on housing provision in the public and private sectors has dominated housing studies ever since Kemeny (1981) dismissed family/community provision as pertaining to underdeveloped societies or to socioeconomically disadvantaged groups. Countering this view has remained comparatively sporadic. However, apart from two decades, the extended-family provision of housing has been the rule not the exception in Romania and has involved a host of diverse economic practices.

\section{An historical account of housing provision}

Romania has long been a rural society. In 1945, only 23\% of the population was urban and was living in small towns, where, like in the villages, the extended-family home dominated the built environment, being self-built with mutual family and community help (Golopentia and Georgescu 1948). Owner-occupation was almost universal, being facilitated by the state's alternative economic practices of land reform. The 1864, 1921, and 1945 reforms redistributed about 8.5 million hectares of land (i.e. 36\% of Romania) from the Church, the gentry, and the Crown, transforming an impoverished peasantry into smallholders practising subsistence agriculture and owning their homes outright (Soaita 2017).

The rupture from the pre-communist way of life was undoubtedly significant, not least in terms of extensive land nationalisation and redefinition of property rights. However, regarding housing provision, the situation continued largely unchanged during the first two decades of communism (Ronnas 1984). During the 1950s-60s, between $70 \%$ and $90 \%$ of new housing in any year was self-built through non-capitalist practices of reciprocal help, mostly in villages and towns. Over this period, families produced about 2.1 million and the state 700,000 units. Constrained by shortages of plots and construction materials, the poor quality of self-building is clear: of all the houses built during this period and still in use by 2011, $46 \%$ and $32 \%$ in rural and urban areas, respectively, are of wattle and daub (NIS 2016).

In the last two decades of communism, the 1970s-80s, the situation reversed. Between $80 \%$ and $95 \%$ of new housing in any year was produced in the anti-capitalist (urban) economy of the state. For instance, in the 1970s, the state produced over 1.3 million units, predominantly urban flats, allocated to relatively privileged workers (Ronnas 1984). Given that self-building was severely constrained, families produced only 325,000 units. Of those still in use by 2011, a quarter of these houses were of wattle and daub (NIS 2016), showing that self-building was still the last resort for many families.

The fall of the communist regime in 1989 was followed by the introduction of (re)privatisation and liberalisation policies in order to build capitalism from scratch. To understand the magnitude of privatisation, suffice to say that about 15 million individuals received privatisation vouchers; 14 million land parcels were restituted; about 2.2 million flats were sold to sitting tenants; and around 200,000 claims for housing restitution were admitted (Soaita 
2017). Whether these diverse economic practices successfully created (capitalist) property markets during the 1990s may be contested. Perturbed by a decade-long economic depression, much of the economic activity took place in the grey economy.

In terms of housing, extended-family provision was dominant but increasingly two-tiered. Selfbuilding became the strategy of the poorest families, producing low-quality homes with significant sweat-equity and reciprocal help; the continuing high share of new wattle-and-daub houses is testimony to this (31\% and 15\% in rural and urban areas). Conversely, self-developing of high-quality, large houses became the prerequisite of advantaged households pursuing alternative economic practices within grey economies (design services, construction materials, and labour). About 200,000 family homes were built during the 1990s while the state delivered 80,000 flats, mainly those unfinished in 1989 (NIS 2016).

Stimulated by economic growth, capitalist/speculative development became visible after 2006, but without constituting a paradigm shift. Within the least financialised EU economy, for-profit developers contributed 3\% of the new housing stock between 1994 and 2015 (vs 86\% by families); less than 1\% of households were mortgagors; $97 \%$ lived in homes they owned outright (NIS 2016); and residential mobility remained the lowest in Eastern Europe (Soaita and Dewilde 2018).

Closer to 'ideal' capitalist economic practices, transactions in the secondary market, mostly cash, tend not to be fully declared. For instance, the difference between the asking price of a two-room flat in Bucharest ${ }^{2}$ averaged $€ 58,200$ versus the notary figure of $€ 40,600$ (Ghira 2018), which is the minimum value accepted for tax purposes in the same area. This suggests undeclared sums may approximate $30 \%$ of the whole transaction, matching Schneider's estimation of the shadow economy in Romania at 28\% of GDP (Schneider 2015).

The dominance of these alternative and non-/anti-capitalist economies of housing provision has clearly contributed to the historically high (outright) homeownership rates in Romania: almost universal prior to 1945, falling to $65 \%$ by the end of communist and about $97 \%$ after 2000 .

\section{Socioeconomic and spatial articulations in housing consumption}

To apply the 'diverse economies' framework to housing phenomena, we should address the quandary of how to measure or adequately proxy the size of these diverse economies that influence housing access and consumption, such as unregistered income from tax evasion, bribes, or gifts (including remittances), state subsidies (including cheap privatisation to sitting tenants), self-provision of services and goods that free up income towards housing costs —all of which are variables not captured in statistics even when specific questions are asked (e.g. Eurostat SILC).

One obvious route is developing rich case studies. Space constraints prevent expanding on the existing literature but to give one example, Soaita (2013) substantiated the articulations between state policies (mobilizing restituted land and privatised flats), grey economies (planning and architectural services, labour, illegal land use) and family practices (pooled-

\footnotetext{
2 Based on 44 listings in Imobiliare.ro (13-Dec-2018) looking for a two-room flat built between 1978 and 1989 in the neighbourhood of Drumul Taberei.
} 
finance for shared living; temporary extreme-overcrowding, early inhabitation) in the selfdeveloping of large, suburban homes.

Building knowledge across researched case studies in different spatial locations will reveal when, where, and how recourse to a host of diverse economic practices strengthens or loosens the link between socioeconomic and housing inequality and what forms of stratification may result. It will also highlight research gaps: for instance, some apartments are bought with stateguaranteed mortgages and it is as yet unknown how these pure capitalist transactions interact with households' other economic practices.

Another route is to devise relevant analytical housing typologies seen as encapsulating particular articulations of the diverse economies of housing provision and consumption, past and present. While these should be theoretically justified, they should also pragmatically match available data. Here I try to sketch such an approach for the Romanian case.

We observed a clear alignment of socioeconomic and housing stratification during communism between houses and flats. Rural houses tended to be homes to households of disadvantaged status whereas urban flats were homes to those in more advantaged social/labour positions. This strong correlation weakened slightly with the development of large, suburban houses in cities and the addition of 'villas' in rural areas; but also with the contrast between the persistent disadvantageous route of self-building and its advantageous new counterpart of selfdeveloping. Nevertheless, the analytical category of housing type - house and flat - remains powerful considering that the stock built after 1990 accounts for only $14 \%$ of the whole (while 74\% was built during communism, NIS 2016).

On the other hand, the distribution of economic power across cities, towns, and villages has persisted if not strengthened to the advantage of cities. If we accept the common wisdom of cities being the economic engines of nations, this has implications for how capitalist economies of the present (like the anti-capitalist economies of the past) mix within household income. For instance, urban professionals were better positioned to appropriate the 'illicit' economies of bribes and tax evasion, given their participation in the public or private sector (Manea 2014). Conversely, rural residents could only mobilise participation in self-provision, seasonal employment, and low state transfers besides strategies of migration (Neef 2002). However, the size of remittances seems to show that urban/rural differentials were not disconnected from differentials in human and social capital. Consequently, the analytical axis of place - rural and urban-remains relevant to the articulation of diverse economies mobilised in housing provision/consumption.

One way to add further spatial nuance to how diverse economies articulate is by differentiating between zones of economic influence of 'successful' cities and zones of economic neglect, but this requires (unavailable) finely grained data-for instance, on the geographical distribution of GDP. Access to infrastructure is an alternative albeit crude way to proxy economic connectivity as well as synergy between public and private economies. Particularly relevant in Romania is the underdevelopment of water/sewage provision in rural areas, which is a marker of spatially and economically disadvantaged places. For instance, in 2011, 29\% of all households lived in homes without sewage provision, $6 \%$ in urban and $58 \%$ in rural areas. While rural housing disadvantage is a legacy of the past, it is reproduced through new construction (about 40\% of houses built after 1990 still lack an indoor water supply and 
sewerage, NIS 2016). Hence, the analytical category of 'rural' could be given added nuance by using utility-connected and utility-disconnected places as a proxy for economic connectivity.

To tease out the analytical relevance of these suggested housing typologies for encapsulating particular articulations of diverse economies of housing provision and consumption, Table 1 presents households' (equivalised) income by quintiles and housing type. ${ }^{3}$ Some patterns are striking and in tune with theoretical expectations.

Table 1: Household income by quintiles and housing type

\begin{tabular}{|c|r|r|r|r|r|}
\hline & \multicolumn{3}{|c|}{ Houses } & \multicolumn{2}{|c|}{ Flats } \\
\cline { 2 - 6 } & Urban & Rural water & Rural no water & Urban & Rural \\
\hline Survey year & 2016 & 2016 & 2016 & 2016 & 2016 \\
\hline $\begin{array}{l}\text { \% of total population } \\
\text { in each type }\end{array}$ & 6.6 & 29.0 & 28.1 & 23.8 & 12.4 \\
\hline Quintile 1 (bottom) & 14.3 & 15.1 & 42.9 & 5.8 & 10.2 \\
\hline Quintile 2 & 14.0 & 23.5 & 29.5 & 9.8 & 13.6 \\
\hline Quintile 3 & 16.6 & 22.0 & 16.1 & 20.1 & 25.9 \\
\hline Quintile 4 & 23.9 & 21.6 & 8.3 & 27.6 & 25.2 \\
\hline Quintile 5 (top) & 31.2 & 17.8 & 3.2 & 36.8 & 25.1 \\
\hline
\end{tabular}

Source: Selected data from Soaita and Dewilde (2018:10), Table 2.

Diverse economic practices, past and present, have produced economic privilege in flats: $65 \%$ of urban flat-residents and $50 \%$ of rural flat-residents belong to the two top quintiles (though there has been a decrease of 2 percentage points since 2007 in cities). Conversely, we see a pattern of extreme poverty and further residualisation in the sector of rural houses without indoor water (a proxy for economically disconnected places, past and present): the share of the bottom two quintiles increased from $69 \%$ to $72 \%$ over the period; the disadvantageous articulations of diverse economic practices have generated resilience - having a self-built roof over one's head - but not an escape from poverty. Interestingly, rural houses with indoor water (a proxy for better connected rural places) show a balanced profile while urban houses display a pattern of fast polarisation, with an increase of 11 percentage points in the top quintile at the expense of the middle ones, reflecting the suburbanisation of economic privilege.

These preliminary findings suggest that diverse economic practices articulate across lines of privilege and exclusion, which can be powerfully mapped across theoretically-informed housing typologies. However, more sophisticated analyses are required to understand the links between housing and socioeconomic stratification and the relevance of these housing typologies to occupancy patterns.

\section{Conclusions}

This brief discussion indicates that the 'diverse economies' framework can enrich accounts of post-communist housing. The simplifying formal/informal assessment of housing provision and consumption is unhelpful since what is 'formal' remains undefined and what is 'informal' conflates very different practices that span socially (un)accepted lawful and unlawful practices;

\footnotetext{
${ }^{3}$ Eurostat SILC data for 2007 (not shown) and 2016 were provided and the analysis conducted by Dr Caroline Dewilde, Tilburg University; weighted results.
} 
economies of benevolence and malevolence; and grey to black economies. Awareness of diverse economies can inform new research questions and devise useful analytical categories, such as housing typologies designed to encapsulate different articulations of economic (dis)advantage. It also guards against uncritical transfers of concepts from afar, such as financialisation, neo-liberalisation, or gentrification, calling instead for thick descriptions of the specific ways in which such processes are domesticated or resisted through practices specific to post-communist conditions (e.g. Górczyńska 2018). Given the 'diverse economies' ontological programme of imagining/constructing post-capitalist futures, further research should address the quandary of where, when, and how diverse economic practices tame, reproduce, or amplify inequalities produced in the capitalist economy. 


\section{References}

Cada, K. 2018. '”They seemed like Super Businessmen:” Financial Instruments in Social Housing Policy.' Critical Housing Analysis 5 (2): 56-67. DOI: 10.13060/23362839.2018.5.2.443.

Cameron, J., J. K. Gibson-Graham 2003. 'Feminising the Economy: Metaphors, Strategies, Politics.' Gender, Place \& Culture 10 (2): 145-157. DOI: 10.1080/0966369032000079569.

Clapham, D., J. Hegedus, K. Kindrea, I. Tosics, H. Kay (eds.) 1996. Housing Privatization in Eastern Europe. London: Greenwood Press.

Ghira, A. 2018. 'Grila Notarilor 2018: valorile apartamentelor din Bucureşti, mai mari cu 2,5\%.’ Economica.net. Retrieved January 20, 2019, from http://www.economica.net/grilanotarilor-2018-valorile-apartamentelor-din-bucuresti-mai-mari-cu-2-5prc_148453.html.

Gibson-Graham, J. K. 2008. 'Diverse economies: performative practices for 'other worlds.' Progress in Human Geography 32 (5): 613-632. DOI: 10.1177/0309132508090821.

Golopentia, A., D. Georgescu 1948. Populatia Republicii Populare Romane. Bucuresti: INS.

Górczyńska, M. 2018. 'Mechanisms of property ownership change and social change in innercity Warsaw (Poland).' Urban Studies 55 (13): 2803-2820. DOI: 10.1177/0042098017730006.

Kemeny, J. 1981. The Myth of Home Ownership. London: Routledge.

Kemeny, J., S. Lowe 1998. 'Schools of Comparative Housing Research.' Housing Studies 13 (2): 161-176. DOI: 10.1080/02673039883380.

Kornai, J. 1992. The Socialist System. Oxford: OUP.

Lux, M., A. Cirman, P. Sunega 2017. 'Housing Restitution Policies among Post-socialist Countries.' International Journal of Housing Policy 17 (1): 145-156. DOI: 10.1080/14616718.2016.1246602.

Manea, T. 2014. 'Medical Bribery and the Ethics of Trust.' Journal of Medicine and Philosophy 40 (1): 26-43. DOI: 10.1093/jmp/jhu049.

Navarro, I. 2013. 'Housing Markets on Cocaine.' Journal of Housing Research 22 (1): 59-74. DOI: 10.5555/jhor.22.1.3239556363470251.

Neef, R. 2002. 'Aspects of the Informal Economy in a Transforming Country.' International Journal of Urban and Regional Research 26 (2): 299-322. DOI: 10.1111/1468-2427.00381.

NIS 2016. Census of Population and Dwellings, Timeline Series. Bucharest: National Institute of Statistics. 
Pavlovskaya, M. 2004. 'Other Transitions: Multiple Economies of Moscow Households in the 1990s.' Annals of the Association of American Geographers 94 (2): 329-351. DOI: 10.1111/j.1467-8306.2004.09402011.x.

Ronnas, P. 1984. Urbanization in Romania. Dissertation, Stockholm School of Economics.

Samers, M. 2005. 'The Myopia of "Diverse Economies", or a Critique of the "Informal Economy".' Antipode 37 (5): 875-886. DOI: 10.1111/j.0066-4812.2005.00537.x.

Schneider, F. 2015. 'Size and Development of the Shadow Economy of 31 European and 5 other OECD Countries from 2003 to 2014.' Journal of Self-Governance and Management Economics 3 (4): 7-29.

Schneider, F., D. Enste 2000. 'Shadow economies.' Journal of Economic Literature 38(1): 77114. DOI: 10.1257/jel.38.1.77.

Smith, A., A. Rochovska 2007. 'Domesticating Neo-liberalism.' Geoforum 36 (6): 1163-1178. DOI: 10.1016/j.geoforum.2007.03.003.

Smith, A., A. Stenning 2006. 'Beyond Household Economies.' Progress in Human Geography 30 (2): 190-213. DOI: 10.1191/0309132506ph601oa.

Soaita, A. M. 2013. 'Romanian Suburban Housing.' Urban Studies 50 (10): 2084-2101. DOI: $10.1177 / 0042098012471980$.

Soaita, A. M. 2017. ‘The Changing Nature of Outright Homeownership in Romania.’ Pp. 236257 in Dewilde, C., R. Ronald (eds.) Housing Wealth and Welfar. Cheltenham: Edward Elgar.

Soaita, A. M., C. Dewilde 2019. 'A Critical-realist View of Housing Quality within the Postcommunist EU States.' Housing, Theory and Society 36 (1): 44-75. DOI: 10.1080/14036096.2017.1383934.

Soaita A. M., C. Dewilde 2018. 'Understanding Housing Stratification through a Production/Consumption View of Diverse Economies.' ENHR International Conference: Migration, densification, segregation, 26 - 29. 7. 2018. Uppsala, Sweden.

Stenning, A. 2005. 'Post-socialism and the Changing Geographies of the Everyday in Poland' Transactions of the Institute of British Geographers 30 (1): 113-127. DOI: 10.1111/j.14755661.2005.00155.x.

Stephens, M., M. Lux, P. Sunega 2015. 'Post-socialist Housing Systems in Europe.' Housing Studies 30 (8): 1210-1234. DOI: 10.1080/02673037.2015.1013090. 